\title{
THE COMPARISON OF DEMONSTRATIVE LEARNING METHOD AND COMPUTER ASSISTED LEARNING ON BLOOD PRESSURE MEASUREMENT AT STIKES GUNA BANGSA YOGYAKARTA
}

\author{
Nur Yeti Syarifah \\ S1 IImu Keperawatan STIKES Wira Husada \\ Jalan Babarsari Glendongan Yogyakarta 55281
}

\begin{abstract}
Rationale: Learning methods in education demand a lecturer not only uses one learning method. It is hoped that the lecturer would deliver an effective and good learning process to his/her students so that the students would achieve better learning results. Therefore, the author is interested to conduct a study"The Comparison of Demonstrative Learning Method and Computer Assisted Learning on Blood Pressure Measurement Guna Bangsa Health College of Yogyakarta in 2012".
\end{abstract}

Objective: Measuring and comparing study result of the students knowledge, effectiveness and skills) after attending one of methods of learning of demonstrative and CAL on blood pressure measurement.

Method:The research samples consist of 76 undergraduates of nursing science which are divided into two groups. This research uses experimental type control time series design which determines the level of the learning skill achieved on measuring the blood pressure, after the students followed demonstrative method of learning and computer assisted learning. The samples are randomized using kind of simple random sampling, which draws members of the population (lottery technique). The instruments used are multiple Choice Question, Checklist and Observation Sheets. The data acquired will be processed and compared using independent $t$ test.

Results: Statistically,significant differences on the results of Students attending methods of learning of demonstrative and CAL on blood pressure measurement.Comparison results of measuring the effectiveness of learning using those methods shows that computer assisted learning method resulting in higher mean than the demonstrative method.

Conclusion: Demonstrative and Computer Assisted Learning Methods are effective learning methods. They could be used to improve the students'knowledge and skills when well applied.

Keywords: Learning Method, Demonstrative, Computer Assisted Learning, Knowledge, Effectivity, Skills, Blood Pressure Measurement

\section{PENDAHULUAN}

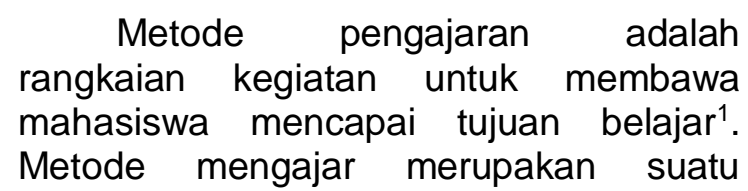

rangkaian kegiatan penyampaian bahan pelajaran kepada mahasiswa agar dapat menerima, menanggapi, mengusai dan mengembangkan bahan pembelajaran ${ }^{2}$.

Praktikum adalah bagian dari pembelajaran yang bertujuan untuk 
menguji dan melaksanakan suatu teori dalam keadaan nyata. Dalam pengertian yang lebih khusus, praktikum merupakan salah satu bentuk kegiatan pembelajaran yang bertujuan untuk memantapkan pengetahuan mahasiswa terhadap materi mata kuliah melalui aplikasi, analisis, sintesis, dan evaluasi terhadap teori yang dilakukan baik di dalam laboratorium ataupun di lapangan.

Pembelajaran skills laboratorium karena pencapaian kompetensi laboratorium klinik diprioritaskan pada yang akan banyak atau yang sering dilakukan kelak atau tindakan yang apabila salah dilakukan akan berakibat fatal, sehingga tidak etis apabila membiarkan pasien yang menderita sakit ditangani oleh mahasiswa yang belum terampil dan keberhasilan pembelajaran keterampilan klinik adalah tersedianya model pembelajaran ${ }^{3}$.

Metode kovensional (ceramah dan demonstrasi) merupakan metode pembelajaran yang berpusat kepada dosen memiliki kelemahan dan oleh berbagai kalangan dianggap telah ketinggalan zaman serta membosankan, mahasiswa cenderung bersikap pasif dan menerima materi kuliah yang diberikan oleh dosen.

Program komputer digunakan untuk menyampaikan pengajaran, alat yang memfasilitasi dalam membelajaran, dan mahasiswa belajar dengan diprogram atau diajar oleh komputer ${ }^{4}$.

\section{METODE}

\section{Rancangan penelitian eksperimental jenis control time series design.} Rancangan penelitian ini terdiri dari 3 hal yang diukur yaitu : (1) pengetahuan mahasiswa yang diukur dengan soal pre test dan post test, (2) efektifitas pembelajaran diukur menggunakan instrument kuestioner dan (3) keterampilan mahasiswa dalam melakukan pengukuran tekanan darah menggunakan checklist. Populasi dalam penelitian ini adalah mahasiswa semester 2 pada Program Studi S-1 IImu Keperawatan STIKES Guna Bangsa Yogyakarta. Jumlah populasi pada penelitian ini sebanyak 88 mahasiswa, dan sampel penelitian berjumlah 88 mahasiswa yang dibagi dalam dua kelompok yaitu kelompok A terdapat 44 mahasiswa yang mengikuti kuliah demonstrasi, dan kelompok B terdapat 44 mahasiswa yang mengikuti kuliah Computer Asissted Learning.

Teknik pengambilan sample pada penelitian ini menggunakan sampel probabilitas (probability samples) jenis acak sederhana (simple random sampling) yaitu setiap anggota atau unit dari populasi mempunyai kesempatan yang sama untuk diseleksi sebagai sampel ${ }^{5}$. Sampel pada penelitian ini disesuaikan dengan kriteria penelitian selanjutnya dibagi kedalam dua kelompok yaitu; mengundi anggota populasi (lottery technique) atau teknik undian berisi angka 1 berjumlah 44 dan angka 2 berjumlah 44, populasi yang mendapat undian berisi angka 1, terdiri dari 44 Mahasiswa masuk ke kelompok $A$ mengikuti kuliah demonstrasi dan 44 mahasiswa yang mendapatkan undian angka 2 masuk ke kelompok $B$ mengikuti kuliah Computer Assisted Learning.

Analisa statistik dalam penelitian ini menggunakan uji one sample Kolmogrof Samirnof, dan uji beda parametrik. Uji beda antara pre-test kelompok A dan post-test kelompok B menggunakan Uji Wilcoxon. Pada uji antara kelompok A dan B baik pengetahuan, efektifitas dan keterampilan menggunakan Independent Sample $T$ Test. Untuk mengetahui perbedaan bermakna pengetahuan pengukuran tekanan darah pada saat post test menggunakan Mann Whitney Test.

\section{HASIL}

\section{Pengukuran Evaluasi Belajar}

Hasil pengukuran pengetahuan mahasiswa diukur dengan multiple choice question (MCQ) yang dilakukan sebelum (Pre-Test) dan sesudah praktikum (Post-Test). Penelitian ini dilakukan pada hari Kamis 29 November 2012 - 13 Desember 2012. Mahasiswa semester satu program studi ilmu keperawatan Sekolah Tinggi Ilmu Kesehatan Guna Bangsa Yogyakarta, yang mengikuti kuliah penelitian ini berjumlah 88 mahasiswa yang dibagi menjadi 2 
kelompok untuk mengikuti praktikum pengukuran tekanan darah.

Kelompok satu mahasiswa mengikuti proses belajar praktikum menggunakan metode demonstrasi masuk kedalam kelompok $A$ dan kelompok dua mengikuti praktikum metode computer assisted learning masuk kedalam kelompok B. setelah satu minggu mahasiswa berkumpul kembali untuk mengikuti post-test yang kedua yaitu pengukuran efektivitas masing-masing metode pembelajaran.

Setelah dua minggu mahasiswa berkumpul kembali di skills Laboratorium keperawatan untuk mengikuti post-tes $t$ yang ketiga yaitu pengukuran keterampilan tekanan darah.
Pembagian kelompok berdasarkan pengambilan undian atau lotre. Keikut sertaan mahasiswa dalam penelitian ini dilakukan secara sukarela setelah mahasiswa menerima penjelasan tentang tujuan dan proses penelitian. Jumlah populasi 88 mahasiswa.

Mahasiswa yang mengikuti penelitian dari awal sampai akhir jalannya penelitian berjumlah 76 Responden, sedangkan 12 mahasiswa lainnya tidak hadir pada pertemuan kedua sehingga dianggap gugur dalam penelitian, yaitu 3 mahasiswa tidak mengikuti pre-test, 6 mahasiswa tidak mengikuti praktikum dan 3 orang lainnya tidak hadir pada pengukuran efektivitas pembelajaran (O3).

Tabel 1. Rata-rata Pre-test, Post-test, selisih Pre-Test dan Post-test Pengetahuan

\begin{tabular}{c|c|c|c|c|c|c}
\hline \multirow{2}{*}{ Kelompok } & \multicolumn{2}{|c|}{ Pre-test } & \multicolumn{2}{c|}{ Post-tets } & \multicolumn{2}{c}{$\begin{array}{c}\text { Selisih Pre-test } \\
\text { dan Post Test }\end{array}$} \\
\cline { 2 - 7 } & $\begin{array}{c}\text { Rata- } \\
\text { rata }\end{array}$ & SD & $\begin{array}{c}\text { Rata- } \\
\text { rata }\end{array}$ & SD & $\begin{array}{c}\text { Rata- } \\
\text { rata }\end{array}$ & SD \\
\hline Demontrasi & 55.263 & 16.2586 & 67.544 & 17.529 & 12.281 & 33.7805 \\
\hline CAL & 52.851 & 17.1415 & 77.632 & 10.089 & 24.781 & 7.636 \\
\hline
\end{tabular}

Hasil Pengukuran pengetahuan mahasiswa dilakukan 2 kali yaitu pada saat pre-test dan post-test. Pre test dilakukan sebelum mahasiswa mendapat materi atau perlakuan dari penelitian di masingmasing kelompok, dan post test pengukuran pengetahuan dilakukan setelah mahasiswa mendapatkan materi pembelajaran praktikum pengukuran tekanan darah.
Tabel 1 merupakan hasil pengukuran pengetahuan metode pembelajaran demonstrasi dan computer assisted learning, dilakukan pada hari Kamis 29 November 2012, pukul $13.00-16.00$ wib di Laboratorium Keperawatan Sekolah Tinggi Ilmu Kesehatan Guna Bangsa Yogyakarta.

Tabel 2. Rata-rata Post-test efektivitas pembelajaran

\begin{tabular}{c|c|c}
\hline \multirow{2}{*}{ Kelompok } & \multicolumn{2}{|c}{ Post Test } \\
\cline { 2 - 3 } & Rata-rata & SD \\
\hline Demonstrasi & 38.13 & 4.709 \\
\hline CAL & 38.87 & 4.557 \\
\hline
\end{tabular}


Hasil Pengukuran Efektivitas Pembelajaran dilakukan setelah satu minggu mahasiswa mengikuti praktikum pengukuran tekanan darah pada masing-masing kelompok. Tabel 2 merupakan hasil pengukuran metode pembelajaran demonstrasi dan computer assisted learning, dilakukan pada hari Jum'at tanggal 7 Desember 2012, pada pukul 13.00 - 13.30 wib di Laboratorium Keperawatan Sekolah Tinggi Ilmu Kesehatan Guna Bangsa Yogyakarta.

Tabel 3. Rata-rata Post-test, keterampilan

\begin{tabular}{c|c|c}
\hline \multirow{2}{*}{ Kelompok } & \multicolumn{2}{|c}{ Post Test } \\
\cline { 2 - 3 } & Rata -Rata & SD \\
\hline Demonstrasi & 80.303 & 7.8611 \\
\hline CAL & 80.263 & 7.6083 \\
\hline
\end{tabular}

Hasil pengukuran keterampilan pengukuran tekanan darah dilakukan setelah dua minggu mahasiswa mengikuti perkuliahan pengukuran tekanan darah pada masing-masing kelompok. Kedua kelompok diwajibkan mengikuti praktikum mandiri masing- masing mahasiswa sebanyak 7 kali. Tabel 3 merupakan hasil keterampilan pengukuran tekanan darah kelompok $\mathrm{A}$ dan B.

2. Analisa Data

a. Analisa Data Peningkatan Pengetahuan

Tabel 4 Hasil Uji Beda Independent T-test dan Mann Whitney test Pengetahuan Mahasiswa

\begin{tabular}{|c|c|c|c|c|c|c|}
\hline \multirow[t]{2}{*}{ Kelompok } & \multicolumn{2}{|c|}{ Pre-Test } & \multicolumn{2}{|c|}{ Post-test } & \multicolumn{2}{|c|}{ Selisih } \\
\hline & Rata- & Independen & Rata-rata & Mann- & Indepen & t T-test \\
\hline Demonstrasi & 55.263 & \multirow[t]{2}{*}{$0.531^{* *}$} & 67.544 & \multirow[t]{2}{*}{$0.014^{*}$} & 12.281 & \multirow[t]{2}{*}{$0.003^{*}$} \\
\hline $\mathrm{CAL}$ & 52.851 & & 77.632 & & 24.781 & \\
\hline
\end{tabular}

Tabel 4 menunjukkan bahwa rata-rata pre-test kelompok A (Demonstrasi) dan B (Computer Assisted Learning) menggunakan Independent T-test secara statistik tidak ada perbedaan yang signifikan pengetahuan mahasiswa sebelum mengikuti pembelajaran pengukuran tekanan darah, yang mengikuti metode pembelajaran CAL dan metode pembelajaran demonstrasi.

Hasil rata-rata post-test A dan B menggunakan Mann-Whitney-Test menunjukkan bahwa ada perbedaan yang signifikan pengetahuan mahasiswa setelah mengikuti pembelajaran pengukuran tekanan darah, yang mengikuti metode pembelajaran CAL lebih tinggi dari pada metode pembelajaran demonstrasi.

Selisih pengetahuan menggunakan Independent T-test secara statistik ada perbedaan yang signifikan antara kelompok yang mengikuti metode pembelajaran metode pembelajaran demonstrasi dan CAL. 
Tabel 5. Hasil Uji Paired-Samples T-Test pengetahuan Mahasiswa

\begin{tabular}{c|c|c|c|}
\hline Kelompok & $\begin{array}{c}\text { Pre-test } \\
\text { (means) }\end{array}$ & $\begin{array}{c}\text { Post-test } \\
\text { (mens) }\end{array}$ & $\begin{array}{c}\text { Paired-Samples } \\
\text { T-Test }\end{array}$ \\
\hline $\begin{array}{c}\text { Demonstra } \\
\text { si }\end{array}$ & 55.263 & 67.544 & $0.000^{*}$ \\
\hline CAL & 52.851 & 77.632 & $0.000^{*}$ \\
\hline \multicolumn{4}{|c}{${ }^{*}$ Bermakna $(p<0.05)$}
\end{tabular}

Tabel 5 menunjukkan bahwa ada perbedaan yang signifikan pengetahuan mahasiswa antara sebelum dan sesudah mengikuti pembelajaran pengukuran tekanan darah kelompok $\mathrm{A}$ dan B. kelompok yang mengikuti

metode pembelajaran CAL mengalami kenaikan lebih tinggi dari pada metode pembelajaran demonstrasi.

Tabel 6 Hasil Uji Independent T-Test Pembelajaran

\begin{tabular}{|c|c|c|}
\hline Kelompok & $\begin{array}{c}\text { Post-test } \\
\text { (Means) }\end{array}$ & Independent T-test \\
\hline Demonstrasi & 38.13 & $0.490^{\star *}$ \\
\hline CAL & 38.87 & \\
\hline \multicolumn{2}{|c|}{${ }^{* \star}$ tidak bermakna $(\mathrm{p}>0.05)$} \\
\hline
\end{tabular}

Tabel 6 menunjukkan bahwa secara statistik tidak ada perbedaan yang signifikan pembelajaran setelah mengikuti pembelajaran pengukuran tekanan darah, yang mengikuti metode pembelajaran CAL dan metode pembelajaran demonstrasi.

c. Analisa Data Keterampilan

Tabel 7 Hasil Uji Mann-Whitney -Test Keterampilan Pengukuran Tekanan Darah

\begin{tabular}{|c|c|c|}
\hline Kelompok & $\begin{array}{c}\text { Post-test } \\
\text { (Mean) }\end{array}$ & $\begin{array}{c}\text { Mann- } \\
\text { Whitney-Test }\end{array}$ \\
\hline Demonstrasi & 80.303 & $0.490^{* *}$ \\
\hline CAL & 80.263 & \\
\hline
\end{tabular}

** tidak bermakna $(p>0.05)$

Tabel 7 menunjukkan bahwa secara statistik tidak ada perbedaan yang bermakna keterampilan mahasiswa setelah mengikuti pembelajaran pengukuran tekanan darah, yang mengikuti metode pembelajaran CAL dan metode pembelajaran demonstrasi

\section{PEMBAHASAN}

1. Perbandingan Mahasiswa Pengetahuan

\section{Hasil Belajar Berdasarkan}

Hasil belajar mahasiswa berdasarkan pengetahuan diukur dengan menggunakan MCQ. Apabila dilihat dari hasil penelitian meggunakan uji beda menunjukkan terjadinya peningkatan pengetahuan pada pretest dan post-test kedua kelompok. Hal ini menunjukkan bahwa kedua metode pembelajaran praktikum demonstrasi dan CAL dapat meningkatkan pengetahuan mahasiswa secara bermakna.

Peningkatan pengetahuan pretest dan post-test kelompok A dan B dilihat menggunakan uji PairedSamples T-Test. Secara statistik menunjukkan bahwa ada perbedaan yang signifikan pengetahuan mahasiswa antara sebelum dan sesudah mengikuti pembelajaran pengukuran 
tekanan darah. Kelompok yang mengikuti metode pembelajaran CAL mengalami kenaikan penge-tahuan lebih tinggi dari pada metode pembelajaran demonstrasi.

Hasil penelitian pengetahuan kelompok $B$ mengalami kenaikan yang lebih tinggi dari pada kelompok $A$, hal ini dikarenakan pada pembelajaran pengukuran tekanan darah kelompok $B$ yang menggunkan VCD pembelajaran tidak hanya dilakukan 1 kali sehingga mahasiswa dapat belajar berulang kali dan tidak di kampus.

Pada kelompok A mahasiswa hanya belajar 1 kali pada saat dosen mendemonstrasikan dan selanjutnya mahasiswa belajar mandiri.

Untuk melihat perbedaan hasil belajar mahasiswa, digunakan uji independent $T$-test, tidak terdapat perbedaan bermakna rata-rata pre-test kedua kelompok, sehingga hasil belajar mahasiswa dilihat dari rata-rata posttest. Rata-rata pos-test menggunakan Mann-Whitney test dan selisih rata-rata menggunakan independen t-test memiliki perbedaan yang signifikan secara statistik. Mahasiswa kelompok $B$ yang mengikuti perkuliahan CAL memiliki pengetahuan yang lebih tinggi, dan bermakna secara statistik.

Apabila dilihat bahwa penelitian menggunakan CAL termasuk kuliah interaktif, maka hasil penelitian ini sama dengan penelitian dari Ruth-Marie (1985) ${ }^{6}$. Penelitian ini melihat perbedaan hasil test metode pengajaran $\mathrm{CAL}$ dan seminar pada kuliah interprestasi EKG. Kedua kelompok mengikuti pre-test yang sama dan diakhiri dengan post-test, setelah rentang waktu enam minggu. Hasil penelitian secara statistik tidak menunjukkan perbedaan yang signifikan akan tetapi terdapat perbedaan mean skor dengan hasil penelitian metode pengajaran CAL lebih tinggi dari pada seminar, sehingga hasil kesimpulan menunjukkan CAL cenderung lebih efektif dari pada metode seminar.

Hasil penelitian ini juga sama dengan penelitian yang dilakukan Petter (2009), membandingkan metode pembelajaran Bed side Teaching (BST) dengan Computer Based Learning (CBL). Hasil analisa statistik menunjukkan peningkatan nilai pre-test dan post-test yang signifikan untuk kelompok $\mathrm{CBL}^{7}$.

\section{Perbandingan Hasil Belajar Mahasiswa Berdasarkan Efektivitas Pembelajaran}

Hasil belajar mahasiswa berdasarkan efektivitas pembelajaran diukur dengan menggunakan kuesioner efektivitas pembelajaran. Dilihat dari hasil penelitian meggunakan independent T-test metode pembelajaran CAL memiliki rerata lebih tinggi dari pada metode pebelajaran demonstrasi.Hasil uji secara statistik menunjukkan tidak ada perbedaan yang signifikan antara efektivitas pembelajaran demonstrasi dan CAL.

Penelitian ini sama dengan penelitian yang dilaporkan oleh Suhoyo $(2008)^{8}$, meneliti empat dari dua belas penelitian randomissed control trial yang menilai efektivitas metode CBL dibandingkan dengan metode pembelajaran lainnya menunjukkan tidak ada perbedaan yang bermakna.

Pada penelitian ini instrument yang digunakan belum baku sehingga peneliti membuat sendiri berdasarkan materi pembelajaran pengukuran tekanan darah, dan kegiatan pembelajaran pengukuran tekanan darah mulai dari tahap pra interkasi sampai terminasi, kemudian data yang disusun mengacu pada penelitian yang pernah dilakukan oleh Nuraini yang berjudul Efektivitas Penerapan Pembelajaran Generatif untuk Meningkatkan Pemahaman Siswa dalam Pelajaran Teknologi Informasi dan Komunikasi. Kemudian instrumen dibuat berdasarkan kerangka Blueprint, setelah itu dilakukan uji validitas dan reabelitas berupa pendapat pakar, yang hasilnya menunjukkan reliabel. 


\section{Perbandingan \\ Mahasiswa Keterampilan}

\section{Hasil Belajar Berdasarkan}

Hasil belajar mahasiswa berdasarkan keterampilan pengukuran tekanan darah diukur dengan menggunakan lembar observasi uji keterampilan praktikum pengukuran tekanan darah. Keterampilan diukur menggunakan Mann-Whitney-Test karena data tidak terdistribusi normal setelah dilakukan uji normalitas dengan one sample kolmogrof Smirnov.Dilihat dari hasil penelitian menggunakan Mann-Whitney-Test menunjukkan tidak ada perbedaan yang signifikan secara statistik antara keterampilan pengukuran tekanan darah demonstrasi dan CAL.

Penelitian ini sama dengan penelitian yang dilakukan oleh $T$ Samuel $(2002)^{10}$ meneliti tentang computer based, perkuliahan biasa dan kombinasi antara keduanya, pada pengajaran parasitologi. Hasil post-test masing-masing kelompok berbeda, akan tetapi memiliki perbedaan yang tidak signifikan secara statistik.

Berdasarkan hasil penelitian diatas (pengetahuan, efektivitas dan keterampilan pengukuran tekanan darah) perbandingan metode pembelajaran Demonstrasi dan Computer Assisted Learning, pada tingkat pengetahuan memiliki kenaikan yang bermakna pre-test dan post-test pada masing-masing kelompok, dan hasil uji statistik menunjukkan perbedaan yang bermakna perubahan pengetahuan mahasiswa setelah perkuliahan di kelompok $A$ dan $B$.

Pada pengukuran efektivitas pembelajaran dan keterampilan terdapat perbedaan mean (rata-rata), akan tetapi hasil secara statistik tidak menunjukkan perbedaan hasil yang bermakna.

\section{KESIMPULAN}

1. Perbandingan hasil pengukuran pengetahuan sebelum dan sesudah perlakuan, didapatkan perbedaan hasil belajar mahasiswa antara kuliah Demonstrasi dan Computer Assisted
Learning yang lebih baik secara statistik.

2. Perbandingan hasil pengukuran efektivitas pembelajaran menggunakan Computer Assisted Learning memiliki hasil yang lebih baik dari pada pembelajaran demonstrasi, akan tetapi hasil perbedaan uji statistik tidak bermakna.

3. Perbandingan pengukuran hasil belajar keterampilan pengukuran tekanan darah, yang menggunakan metode belajar demonstrasi memiliki nilai mean yang lebih tinggi dari pada computer assisted learning, namun perbedaannya tidak bermakna.

\section{SARAN}

1. Walaupun hanya terdapat 1 perbedaan yang bermakna secara statistik, terhadap hasil belajar pada mahasiswa yang mengikuti kuliah Demonstrasi dan Computer Assisted Learning, namun pembelajaran CAL dapat meningkatkan pengetahuan mahasiswa program studi ilmu keperawatan Sekolah Tinggi IImu Kesehatan Guna Bangsa Yogyakarta. Melihat hasil tersebut, peneliti menyarankan bahwa metode ini dapat di gunakan sebagai alternative metode kuliah interaktif yang dapat diterapkan, terutama bagi dosen yang hanya memiliki tidak banyak waktu dalam proses belajar mengajar karena kesibukan atau beban pekerjaan lainnya, sehingga mahasiswa dapat mengulang pembelajaran tidak harus di kampus.

2. Dalam proses pembelajaran praktikum hendaknya ditempatkan di kelas yang berbeda sehingga tidak mengganggu aktivitas belajar di kelas lainnya yang dapat mempengaruhi hasil pengukuran pembelajaran dalam penelitian.

3. Metode pembelajaran CAL, termasuk metode kuliah interaktif hendaklah mempertimbangkan fasilitas lainnya yang lebih mendukung seperti pengeras suara yang berkualitas, TV dan VCD yang memadai, serta ruangan yang representative, sehingga dapat meningkatkan kualitas 
pembelajaran interaktif, yang dapat mempengaruhi efektivitas hasil belajar mahasiswa.

\section{DAFTAR PUSTAKA}

1.DeJong G.(1992). Batavia AJ, Mcknew LB.The Independent Living Model of Personal Assistance in National Long-Term Care Policy. Generations;16(1):8995.

2.Berk R.A. (2005). International Journal of Teaching and Learning in Higher Education Volume 17, Number 1, 48-62 2005, Volume 17, Number 1, 48-62. Tersedia dalam; http://www.isetl.org/ijtlhe/ http://www.isetl.org/iitlhe

3.Samsudin, et all. (2007). Kegiatan Praktikum dan Inkuiri. Makalah Tidak Dipublikasikan. Bandung: SPs UPI
4.Notoadmojo, S. (2010). Metodologi Penelitian Kesehatan. Rineka Cipta. Jakarta.

5. Merel. (2009). Student view on the efective teaching of physical examination skill; qualitative study

6. Doty P. (2000). The Federal Role in the Move toward Consumer Direction.

Generations;XXIV(111):22-7.

7.Suhoyo, Y. (2008). Perbandingan Efektifitas CBL dan Kuliah pada Pengajaran Prinsip Dasar Bioetik pada Mahasiswa Baru Fakultas Kedokteran. Tesis, S2 IPK.FK UGM. Yogyakarta

8.Greenberg, D. (1999). Shroder M, Onstott M. The Social Experiment Market. Journal of Economic Perspectives;13(3):157-72

9.Evans.2008.can medical student from two culture learn effective from a shared web based learning enviritmen 